\title{
Mid-Urethral Sling for Stress Incontinence: Does Urodynamic Pressure Reading Affect Post-Operative Outcome?
}

\author{
Abdullah Ghazi ${ }^{1}$, MD, SSc-URoL, Ali Alabbad ${ }^{1}$, MD, SSC-URoL, Malak Abuzgaya ${ }^{1}$, MD, \\ Mai A. Banakhar', MD, SSC-URoL, Dean S. Elterman', MD, FRCS, Sidney Radomski', MD, \\ FRCS, PhD, Magdy Hassouna', MD, FRCS, PhD \\ 'Department of Urology, Toronto Western Hospital, Toronto, Canada \\ ${ }^{2}$ Department of Urology, Faculty of Medicine, King Abdulaziz University, Jeddah, Saudi Arabia
}

\section{Correspondence}

Dr. Mai A. Banakhar

Department of Urology, Faculty of Medicine

King Abdulaziz University

P.O. Box 80215, Jeddah 21589

Saudi Arabia

e.M: drmaibanakher@hotmail.com

Submission: 13 May 2019

Accepted: 27 May 2019

\section{Citation}

Ghazi A, Alabbad A, Abuzgaya M., Banakhar AA, Elterman DS, Radomski S, Hassouna M. Mid-urethral sling for stress incontinence: does urodynamic pressure reading affect postoperative outcome? JKAU Med Sci 2019; 26 (1): 11-18. DOI: 10.4197/Med. 26-1.3

Copyright: (The Author(s), YEAR. Publisher. The Journal of King Abdualziz University - Medical Sciences is an Official Publication of "King Abdulaziz University". It is an open-access article distributed under the terms of the Creative Commons Attribution Non-Commercial License, which permit unrestricted non-commercial use, distribution, and reproduction in any medium, provided the original work is properly cited.

\begin{abstract}
The aim of our study was to determine the effect of preoperative urodynamic reading of Valsalva leak point pressure on the result of mid-urethral sling surgery. From January 2010 to December 2014, a total of 207 patients underwent mid-urethral sling surgery at the Toronto Western Hospital. An incontinence questionnaire was sent to 94 patients who accepted to be involved in the study to examine satisfaction post-surgery. Forty-five patients replied and were included in the analysis. The patients were divided into three groups according to valsalva leak point pressure $(<60,60-80$ and $>$ $80 \mathrm{~cm} \mathrm{H}_{2} \mathrm{O}$ ) determined on urodynamic testing. Of the forty-five patients who responded to the questionnaire, seven were excluded for only having had stress testing done and two were excluded due to intermittent catheterization. Thirteen patients had evidence of detrusor overactivity on urodynamic testing. Simple linear regression analysis was done for the three groups of the Valsalva leak point pressure values and correlation to satisfaction was found -0.263 , -0.236 , and -0.148 , respectively. In this current study, we could not find a relation between valsalva leak point pressure values and the selfreported satisfaction post-surgical correction.
\end{abstract}

\section{Keywords}

Stress incontinence; mid-urethral sling; Valsalva leak point pressure center

\section{Introduction}

rodynamic reading of Valsalva leak point pressure (VLPP) is associated with stress urine incontinence in the absence of detrusor overactivity ${ }^{[1,2]}$. It is used to classify urine incontinence severity and differentiate between women who have intrinsic sphincter deficiency and those who have urethral hypermobility ${ }^{[3]}$.

However, the use of VLPP value in patients with stress urine incontinence to help in the decision making 
to cure the stress incontinence of urine surgically remains undecided partly because the methodology of performing these measurements has not been standardized ${ }^{[4-6]}$.

In the current study we examined the role of VLPP in predicting the satisfaction rate in the surgical outcome of female patients who undergo a mid-urethral sling procedure irrespective to the manufacturer of the sling.

\section{Patients and Methods}

This retrospective study reviewed the charts of 207 patients who underwent mid-urethral sling procedures for stress urinary incontinence from January 2010 to December 2014 at the Toronto Western Hospital. Research ethics board at the University Health Network accepted the protocol. The consent and validated questionnaire (Norwegian Female Incontinence Questionnaire for Urinary Incontinence. Appendix 1) was mailed to 94 patients who accepted to be involved in the study with a prepaid return envelope. Forty-five patients replied and were included in the analysis. Nine patients were excluded, two on intermittent catheterization and seven whom had only a stress test. Patients were divided into three groups according to the VLPP values:

- Group 1: VLPP $<60 \mathrm{~cm} \mathrm{H}_{2} \mathrm{O}(\mathrm{n}=9)$

- Group 2:VLPP 61-80 $\mathrm{cm} \mathrm{H}_{2} \mathrm{O}(\mathrm{n}=14)$

- Group 3: VLPP $>80 \mathrm{~cm} \mathrm{H}_{2} \mathrm{O}(\mathrm{n}=13)$

All patients underwent a mid-urethral sling surgery based on the surgeon's preference, which are tensionfree vaginal tape (TVT) (1), in/out transobturator tape (TOT) (23), out/in TOT (6), single incision TOT (5) and TVT cadaveric graft (1).

Table 1. Patients demographics

\begin{tabular}{|l|c|}
\hline \multicolumn{1}{|c|}{ Total Number } & $\mathrm{N}=45$ \\
\hline Age & Mean $60 \mathrm{y}$ \\
\hline Questionnaire & Mean score 18.62 (min 0 - max 51) \\
\hline VLPP $<60 \mathrm{~cm} \mathrm{H}_{2} \mathrm{O}$ & 9 \\
$61-80 \mathrm{~cm} \mathrm{H}_{2} \mathrm{O}$ & 14 \\
$>80 \mathrm{~cm} \mathrm{H}_{2} \mathrm{O}$ & 13 \\
Excluded & 2 on CIC \\
& 7 only stress test done \\
\hline Detrusor over activity & 12 Yes \\
& 23 Absent \\
\hline
\end{tabular}

VLPP: Valsalva leak point pressure

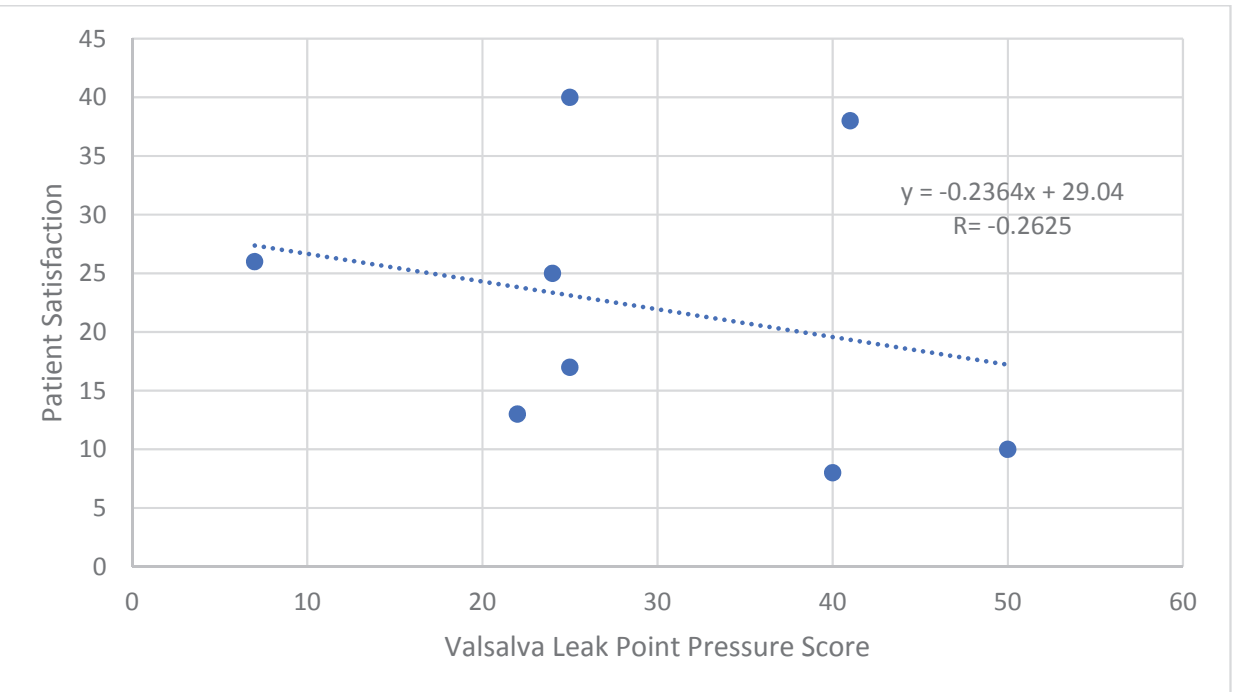

Figure 1. Correlation between Valsalva leak point pressure score $\left(<60 \mathrm{~cm} \mathrm{H}_{2} \mathrm{O}\right)$ and patient satisfaction. 


\section{Results}

The questionnaire was mailed to 94 patients. Fortyfive patients replied and were included in the analysis. Their mean age was 60.2 (42-89) years old. Mean questionnaire total score was 18.62 (score range from $2-40$, with questionnaire scoring 0 totally satisfied and 58 totally unsatisfied). Nine patients were excluded. Two on intermitted catheterization and seven of whom had only a stress testing performed. Twelve patients had evidence of detrusor overactivity on urodynamic test (Table 1).
After the simple linear regression analysis, and the correlation variable was calculated it was discovered that patients who have stress urinary incontinence that undergo surgery with a VLPP score of $<60 \mathrm{~cm} \mathrm{H}_{2} \mathrm{O}$, $61-80 \mathrm{~cm} \mathrm{H}_{2} 0$, and $>80 \mathrm{~cm} \mathrm{H}_{2} 0$ were found to have a negative correlation variable of $-0.263,-0.236$, and -0.148 , respectively (Fig. 1,2 and 3 ).

Therefore, it is concluded for patients with VLPP scores of $<60,61-80$, and $>80 \mathrm{~cm} \mathrm{H}_{2} 0$ that there is a weak negative correlation between the patients VLPP score and their satisfaction.

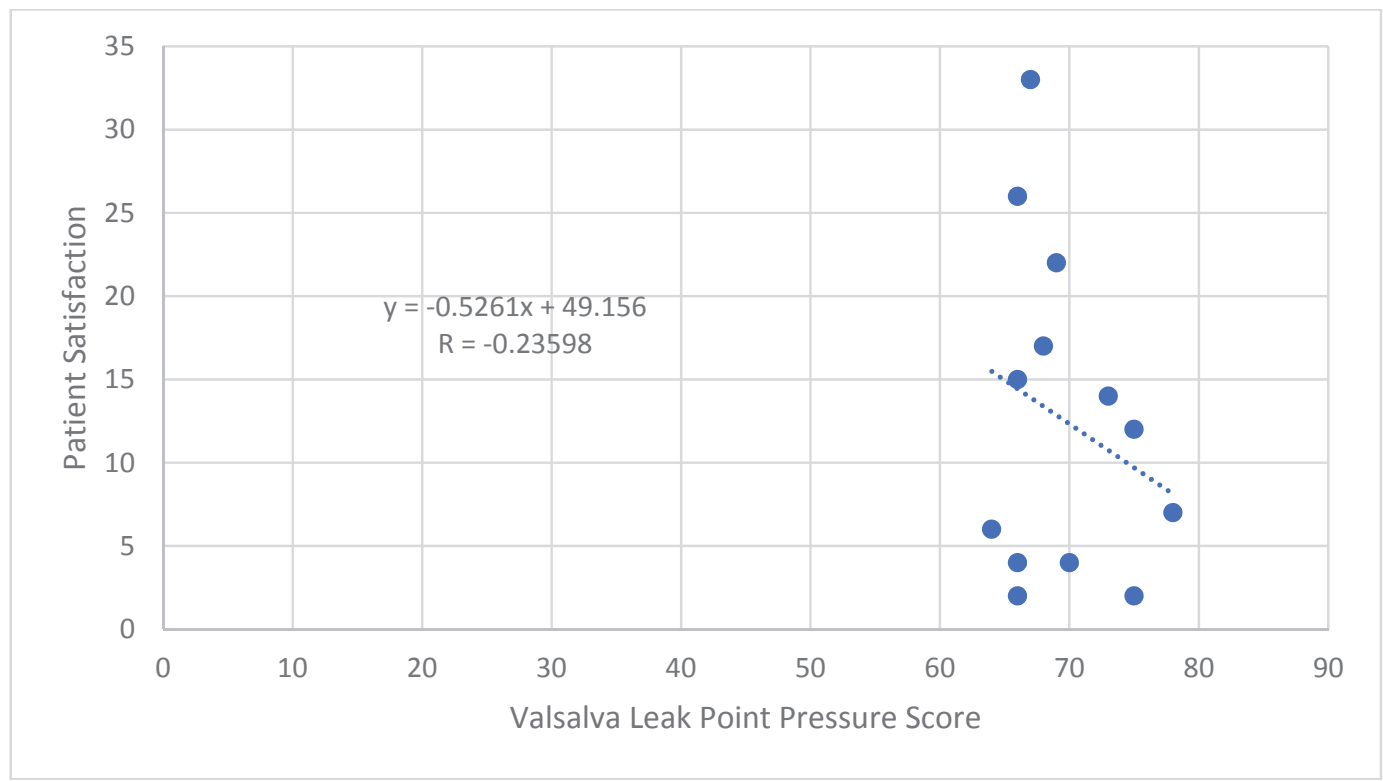

Figure 2. Correlation between Valsalva leak point pressure score $\left(61-80 \mathrm{~cm} \mathrm{H}_{2} \mathrm{O}\right)$ and patient satisfaction.

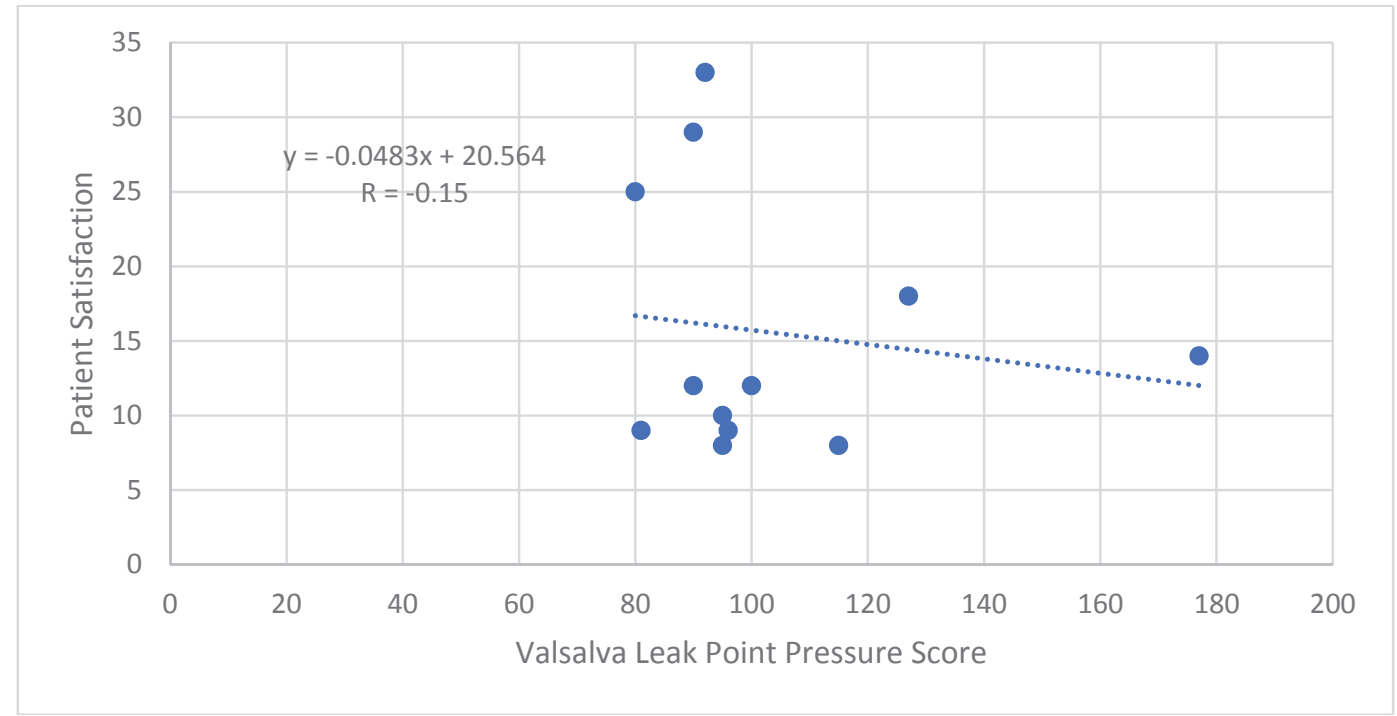

Figure 3. Correlation between Valsalva leak point pressure score ( $>80 \mathrm{~cm} \mathrm{H}_{2} \mathrm{O}$ ) and patient satisfaction. 
Mid-Urethral Sling for Stress Incontinence: Does Urodynamic Pressure Reading Affect Post-Operative Outcome?

A. Ghazi et al.

Table 2. Simple linear regression analysis between the three groups

\begin{tabular}{|c|c|c|c|c|}
\hline Variable & VLPP $\left(\mathrm{cm} \mathrm{H}_{2} \mathbf{0}\right)$ & Number & Mean Rank & Significance \\
\hline Questionnaire & $<60$ & 9 & 21.55 & $\mathrm{P}=0.26$ \\
& $61-81$ & 14 & 13.5 & $\mathrm{P}=0.24$ \\
& $>80$ & 13 & 13 & $\mathrm{P}=0.15$ \\
\cline { 2 - 5 } & \multicolumn{3}{|c|}{ Mean 16.6 (Min 2- Max 40) } \\
\hline
\end{tabular}

VLPP: Valsalva leak point pressure

Table 3. Chi-squared test for detrusor overactivity categories against Valsalva leak point pressure groups

\begin{tabular}{|l|c|c|c|}
\hline Variable & VLPP $<60 \mathrm{~cm} \mathrm{H}_{2} \mathbf{O}$ & VLPP 61-80 $\mathrm{cm} \mathrm{H}_{2} \mathbf{O}$ & VLPP $>80 \mathrm{~cm} \mathrm{H}_{2} \mathbf{O}$ \\
\hline Detrusor Overactivity & & & 5 \\
Present & 6 & 2 & 8 \\
Absent & 3 & 11 & $\mathrm{P}=0.45$ \\
\hline Age & $\mathrm{P}=0.269$ & $\mathrm{P}=0.265$ & 5 \\
& & & 5 \\
$50-50$ & 1 & 1 & 1 \\
$61-60$ & 4 & 3 & 2 \\
$>70$ & 2 & 3 & $\mathrm{P}=0.681$ \\
\hline
\end{tabular}

VLPP: Valsalva leak point pressure

Pearson's chi-squared test for age and detrusor overactivity categories between VLPP groups showed no significant difference (Table 2 and 3 ).

\section{Discussion}

Currently there is no clearly defined consensus on the necessity of preoperative urodynamics (UDS) before offering any surgical correction for female patients with stress urinary incontinence. It seems reasonable to perform UDS investigations in patients with mixed symptoms, failed previous surgery, persistent symptoms ${ }^{[7]}$ or with the presence of genital prolapse $\mathrm{e}^{[8]}$.

In a series reported by Abdel-Hady and Constantine ${ }^{[9]}$ they found high efficacy of TVT as the first choice of treatment for women with stress urine incontinence, including those with low VLPP. In a different study, Spinosa and Dubuis ${ }^{[10]}$ reported effect of VLPP on patient outcome.

McGuire et al. ${ }^{[11-13]}$ suggested that stress incontinence is due to intrinsic urethral sphincteric deficiency if the VLPP was under $60 \mathrm{~cm} \mathrm{H}_{2} \mathrm{O}$.

But in a recent report by lancu and Peltecu ${ }^{[7]}$, they reported that a low VLPP (usually less than $60 \mathrm{~cm} \mathrm{H}_{2} \mathrm{O}$ ) on urodynamic studies may be considered to be a risk factor for treatment failure ${ }^{[7,14-18]}$.

In the present study, we include all patients who had evidence of stress urinary incontinence based on patient history and UDS finding. All patients underwent a mini-urethral sling surgery based on the surgeon's preference which where TVT, TOT both autologous, synthetic and /or cadaveric. The purpose of the present study was not to compare the satisfaction of any surgical technique, but our main objective was to correlate the VLPP value with the outcome of the surgical procedure. We divided the patients for this aim according to the VLPP values into three categories: VLPP values $(<60,60-$ 80 and $>80 \mathrm{~cm} \mathrm{H}_{2} \mathrm{O}$ ). Despite those categories the VLPP did not show a statistical difference in the outcome of the mid-urethral sling surgery. The Norwegian Female Incontinence Questionnaire for Urinary Incontinence was used to evaluate the postoperative symptoms and it did not show a difference in satisfaction score between different VLPP values.

We are aware of some limitation in this study: it is retrospective. The number of patients was limited small and there were different procedure techniques used in those patients. The questionnaire for the patient satisfaction was done only in the postoperative period. 
Mid-Urethral Sling for Stress Incontinence: Does Urodynamic Pressure Reading Affect Post-Operative Outcome?

A. Ghazi et al.

\section{Conclusion}

We could not find a relation between VLPP values satisfaction outcome of mid-urethral sling surgical correction for stress urinary incontinence.

\section{Conflicts of Interest}

The authors declare no conflict of interest.

\section{Disclosure}

The authors did not receive any type of commercial support either in forms of compensation or financial for this study. The authors have no financial interest in any of the products or devices, or drugs mentioned in this article.

\section{Ethical Approval}

Obtained.

\section{References}

[1] Abrams P, Cardozo L, Fall M, Griffiths D, Rosier P, Ulmsten $U$, van Kerrebroeck $P$, Victor A, Wein A. The standardisation of terminology of lower urinary tract function: report from the Standardization Sub-committee of the International Continence Society. Am J Obstet Gynecol 2002; 187(1): 116-126.

[2] Cobreros C, Rosier P. Valsalva leak point pressure. ICS wiki website. (http://wiki.ics.org/ Valsalva+Leak+Point+Pressure).

[3] McGuire EJ. Urodynamic evaluation of stress incontinence. Urol Clin North Am 1995; 22(3): 551-555.

[4] Fletcher SG, Lemack GE. Clarifying the role of urodynamics in the preoperative evaluation of stress urinary incontinence. Scientific World J 2008; 8: 1259-1268.

[5] Nitti VW, Combs AJ. Correlation of valsalva leak point pressure with subjective degree of stress. J Urol 1996; 155(1): 281-285.

[6] Bump RC, Elser DM, Theofrastous JP, McClish DK. Valsalva leak point pressures in women with genuine stress incontinence: reproducibility, effect of catheter caliber, and correlations with other measures of urethral resistance. Continence Program for Women Research Group. Am J Obstet Gynecol 1995; 173(2): 551-557.

[7] lancu G, Peltecu G. Predicting the outcome of midurethral tape surgery for stress urinary incontinence using preoperative urodynamics - a systematic review. Chirurgia (Bucur) 2014; 109(3): 359-368.

[8] Serati M, Salvatore S, Siesto G, Cattoni E, Braga A, Sorice P, Cromi A, Ghezzi F, Bolis P. Urinary symptoms and urodynamic findings in women with pelvic organ prolapse: is there a correlation? Results of an artificial neural network analysis. Eur Urol 2011; 60(2): 253-260.

[9] Abdel-Hady el-S, Constantine G. Outcome of the use of tension- free vaginal tape in women with mixed urinary incontinence, previous failed surgery, or low valsalva pressure. J Obstet Gynaecol Res 2005; 31(1): 38-42.

[10] Spinosa JP, Dubuis PY. Suburethral sling inserted by the transobturator route in the treatment of female stress urinary incontinence: preliminary results in 117 cases. Eur J Obstet Gynecol Reprod Biol 2005; 123(2): 212-217.

[11] McGuire EJ, Fitzpatrick CC, Wan J, Bloom D, Sanvordenker J, Ritchey M, Gormley EA. Clinical assessment of urethral sphincter function. J Urol 1993; 150(5 Pt 1): 1452-1454

[12] Juma S, Brito CG. Transobturator tape (TOT): Two years follow-up. Neurourol Urodyn 2007; 26(1): 37-41.

[13] Ryu JG, Yu SH, Jeong SH, Yun BH, Yu HS, Kim SO, Kwon D. Transobturator tape for female stress urinary incontinence: preoperative valsalva leak point pressure is not related to cure rate or quality of life improvement. Korean J Urol 2014; 55(4): 265-269.

[14] Rodríguez LV, de Almeida F, Dorey F, Raz S. Does Valsalva leak point pressure predict outcome after the distal urethral polypropylene sling? Role of urodynamics in the sling era. J Urol 2004; 172(1): 210-214.

[15] Toledo LG, Cabral PH, Casella ML, Politi GE, Cardoso SN, Mello LF, Glina S. Prognostic value of urethral mobility and valsalva leak point pressure for female transobturator sling procedure. Int Braz J Urol 2012; 38(5): 667-673.

[16] Costantini E, Lazzeri M, Giannantoni A, Bini V, del Zingaro M, Porena M. Preoperative MUCP and VLPP did not predict long-term (4-Year) outcome after transobturator midurethral sling. Urol Int 2009; 83(4): 392-398.

[17] Kawasaki A, Wu JM, Amundsen CL, Weidner AC, Judd JP, Balk EM, Siddiqui NY. Do urodynamic parameters predict persistent postoperative stress incontinence after midurethral sling? A systematic review. Int Urogynecol J 2012; 23(7): 813-822.

[18] Nager CW, Kraus SR, Kenton K, Sirls L, Chai TC, Wai C, Sutkin G, Leng W, Litman H, Huang L, Tennstedt S, Richter HE; Urinary Incontinence Treatment Network. Urodynamics, the supine empty bladder stress test, and incontinence severity. Neurourol Urodyn 2010; 29(7): 1306-1311. 


\section{Norwegian Female Incontinence Questionnaire for Urinary Incontinence Pre- and Postoperative Recording}

Date for questionnaire completion

Patient number

Please answer all questions.

\begin{tabular}{|llll}
\hline (Mark yes, no or not relevant for each alternative in question 1) & & & \\
\hline 1. Do you leak urine? & & & \\
when you cough & $\square$ Yes & $\square$ No & $\square$ Not relevant \\
when you sneeze & $\square$ Yes & $\square$ No & $\square$ Not relevant \\
when you laugh & $\square$ Yes & $\square$ No & $\square$ Not relevant \\
when you walk up or down the stairs & $\square$ Yes & $\square$ No & $\square$ Not relevant \\
when you get out of bed & $\square$ Yes & $\square$ No & $\square$ Not relevant \\
when you lift heavy objects & $\square$ Yes & $\square$ No & $\square$ Not relevant \\
during physical activity (e.g. running to catch the bus) & $\square$ Yes & $\square$ No & $\square$ Not relevant \\
during sports & $\square$ Yes & $\square$ No & $\square$ Not relevant \\
during intercourse & $\square$ Yes & $\square$ No & $\square$ Not relevant
\end{tabular}

(Mark only one alternative for each question from 2 - 6)

2. How often do you leak urine in relation to physical activity, when you laugh, cough or sneeze?

$\square$ Never

$\square$ 1-4 times each month

$\square$ 1-6 times each week

$\square$ Once per day

$\square$ More than once per day

3. How much urine do you usually leak during physical activity or when you laugh, cough or sneeze? $\square$ Nothing

$\square$ Drops/ moist underwear

$\square$ Dripping/ wet underwear

$\square$ Running/ passes through all your clothes

$\square$ Running down your legs or down onto the floor

4. How often do you experience sudden and imperious urge to void leading to urinary leakage before you reach the toilet?

$\square$ Never

$\square$ 1-4 times each month

$\square$ 1-6 times each week

$\square$ Once per month

$\square$ More than once per day

5. How large is the amount of urine you usually leak when you experience sudden and imperious need to void and urinary leakage?

$\square$ Nothing

$\square$ Drops/moist underwear

$\square$ Dripping/ wet underwear

$\square$ Running/ passes through all your clothes

$\square$ Running down your legs or down onto the floor

6. If you experience both the symptoms described in question 2 and question 4 , what is troubling you the most?

$\square$ Leakage during physical activities more than leakage related to urgency?

$\square$ Leakage related to urgency more than during physical activity?

$\square$ Equally trouble by leakage related to urgency as by a leakage during physical activity?

$\square$ I don't have leakage as described in question 2 or question 4 
Appendix 1 (CONTINUED)

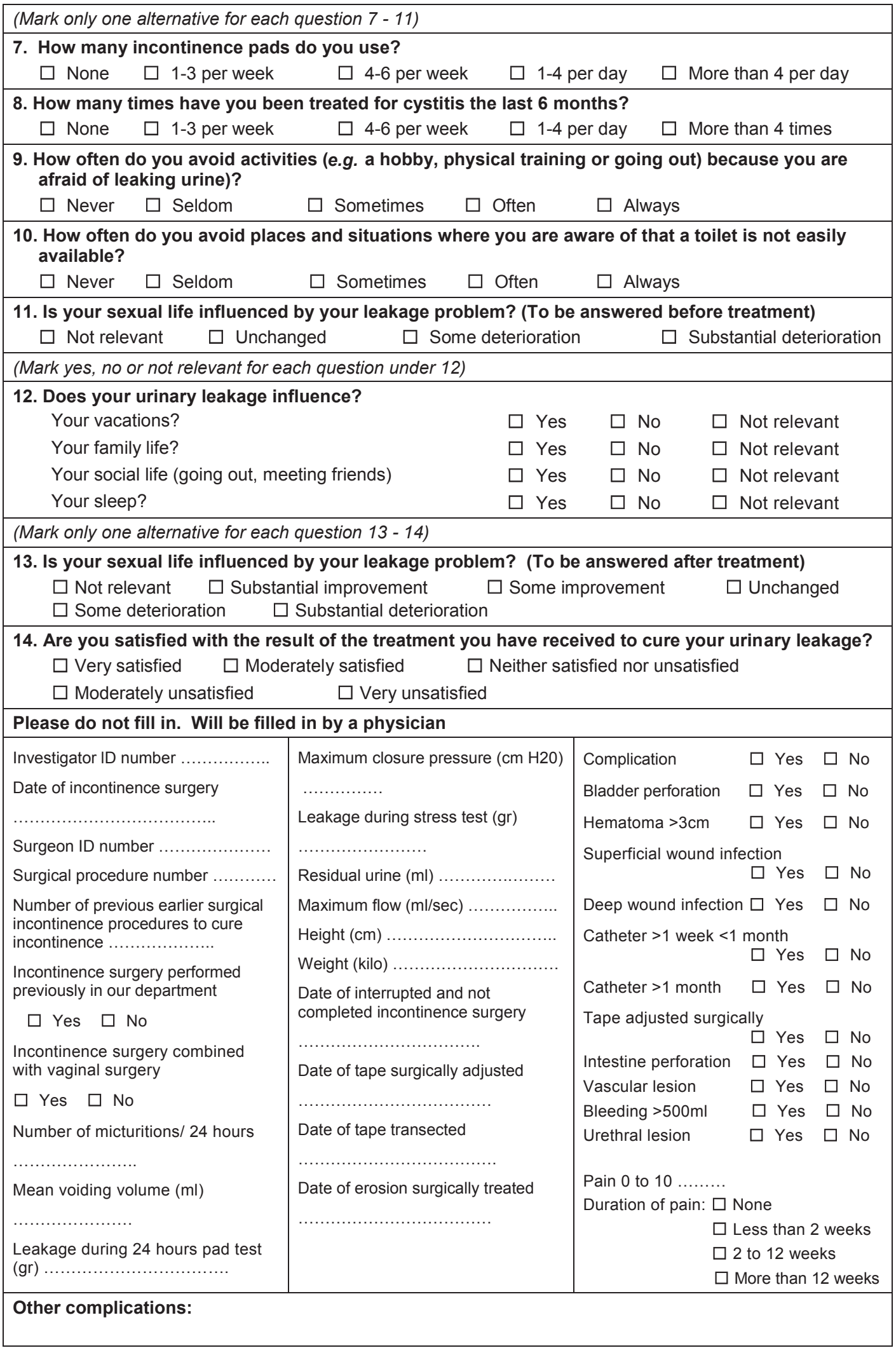


تاثثير ضغط المثانه في سلس البول الاجهادي وتاثيره على نتائج عمليات شريط

عبدالله غازي' و علي العباد' و ملك ابو زيقا' و مي احمد بانخر ' و دين التيرمان' و سيدني

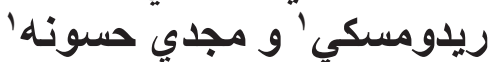

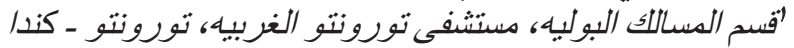

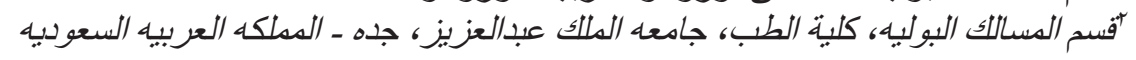

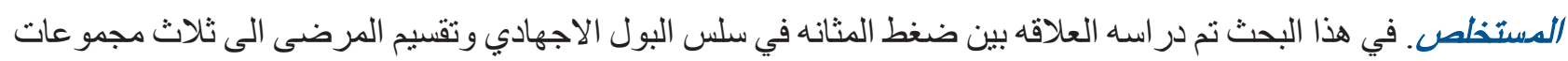

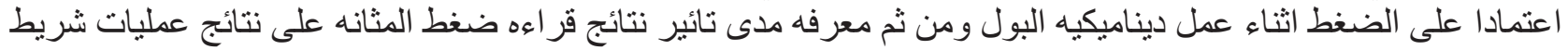

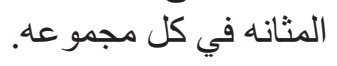

